\title{
連続染色加工装置の省エネルギー
}

\author{
山東幸司 SANDOU Kouji \\ 株式会社山東鐵工所
}

\section{1. 連続染色加工装置}

一般的に連続染色加工装置は，木綿およびその混紡品 織物等を大量に加工する装置. すなわち毛焼装置 $\rightarrow$ 糊 抜・精練 $\rightarrow$ 漂白 $\rightarrow$ マーセライズ $\rightarrow$ パッドドライ $\rightarrow$ パッドスチームの一連の工程が主にイメージされる。 これらは第二次世界大戦後の 1950～60年代に欧米で開 発され, その後, 日本に装置が導入された. 1970年代 以降は日本製が国内に 1980 年代には東南アジアにも普 及し，中国やインドにも波及している。

これらの代表的な木綿およびその混紡品織物等を大量 に加工する装置はその加工工程のほぼすべてが連続的に 処理されるが，この連続方式に対峙する方式としてバッ チ(回分)方式がある. ポリエステル織編物の染色加工に 代表されるように, 今日でも多くの工程がバッチ処理で 加工が行われている.

個々の工程をバッチ式で行うことは加工単位 $\left(\mathrm{m}^{2} 、 \mathrm{~kg}\right)$ では多くの資源（エネルギー，染薬剂，水）の消費が多 い.しかし，マイナーな要素を持つバッチ式が今日多く 採用されているのは, 被加工品が素材や構造の理由から, 連続式になじまないものがあるからである．連続式にマ ッチしない素材は以下のようなものである.

（1）素材が加圧（100 $\mathrm{C}$ 以上）での処理が原則である 素材 (ポリエステル素材等).

（2）布状以外の，カセやチーズといった糸や綿.

（3）編み物や弾性糸が織り込まれた布のように張力を 掛けると変形しやすい素材.

（4）絹，羊毛，レーヨン等の物理的に脆弱な素材

（5）レース等の組織が不均衡な布地

（6）ベルベットやコージュロイ等の立毛素材

（7）タオル等のパイル織物・編物

（8）1色当たりのロットが小さく，短納期の注文 つまり, シャツ地やシーツ, 作業着等の生地が緻密で 変形しにくい素材においては連続法が有利であるが, 常 圧下で染まらないもの（ポリエステル等）は連続法には 適さない.

このことは, バッチ法による染色加工となり基本的に 多くのエネルギーや資源を消費する加工法となる.
なおバッチ式でも, 一つの装置で複数の工程を行うも のと, 工程により装置を変更する場合があって, 連続式 のように一定の工程パターンが組めないものも多数あ る.

さらに，従来はバッチ式が主体であったものが新たな 装置の開発により連続法に切り替えが行われ（例えば, リラクシングや減量加工, 捺染品の発色やその後の水洗 工程, 木綿編物のマーセライズ, デニム用インジゴ染色), 資源, エネルギー消費を抑える努力が進められている.

\section{2. 毛焼装置}

短繊維織編物の毛羽を除去する最も有効な手段とし て, 高温のバーナーで毛羽を焼き切る方法が採られる. 熱源はLPGや天然ガスが使用される．織機や編み機の 広幅化に伴い働き幅がより広くなりすべての炎を均一に 燃焼するため, 山東鐵工所のサンジェットバーナー（図 1）では，ガス調圧機構や燃焼幅調整機構を自動化し燃 焼ガス量の低減を行っている.

\section{3. 糊抜き・精練装置}

織機の高速化に伴いより強力な経糸糊剤が使用される ようになり，今日ではPVAとシリコン油剂が主な糊剂 成分である．このPVAを除去するには高温水による膨 潤と酸化糊抜き剤によるPVAの可溶化が必要である. 最近の技術では表面分布するPVAの膨潤には数分間の 高温水での処理が必要で, 次段のサチュレータで酸化糊 抜き剤と, か性ソーダ, 活性剤, キレート剤を付与して リアクターで蒸熱処理を行う.

作業服やパンツ素材等の厚生地では経糸糊剂の単位当 たり絶対量が多いために, 精練工程の前に糊抜き工程を 入れることも重要である. 過炭酸塩等による酸化糊抜き 法は比較的短時間（5〜10分程度）の蒸熱でPVAの可 溶化が容易になり, 後の精練工程での負荷が軽減できる ので, 染色不良等の歩留まり改善の面でも有効な手段で ある.この目的にはラウンドパイル型のリアクターやロ ーラータイプのスチーマーで発色装置より布容量の大き 

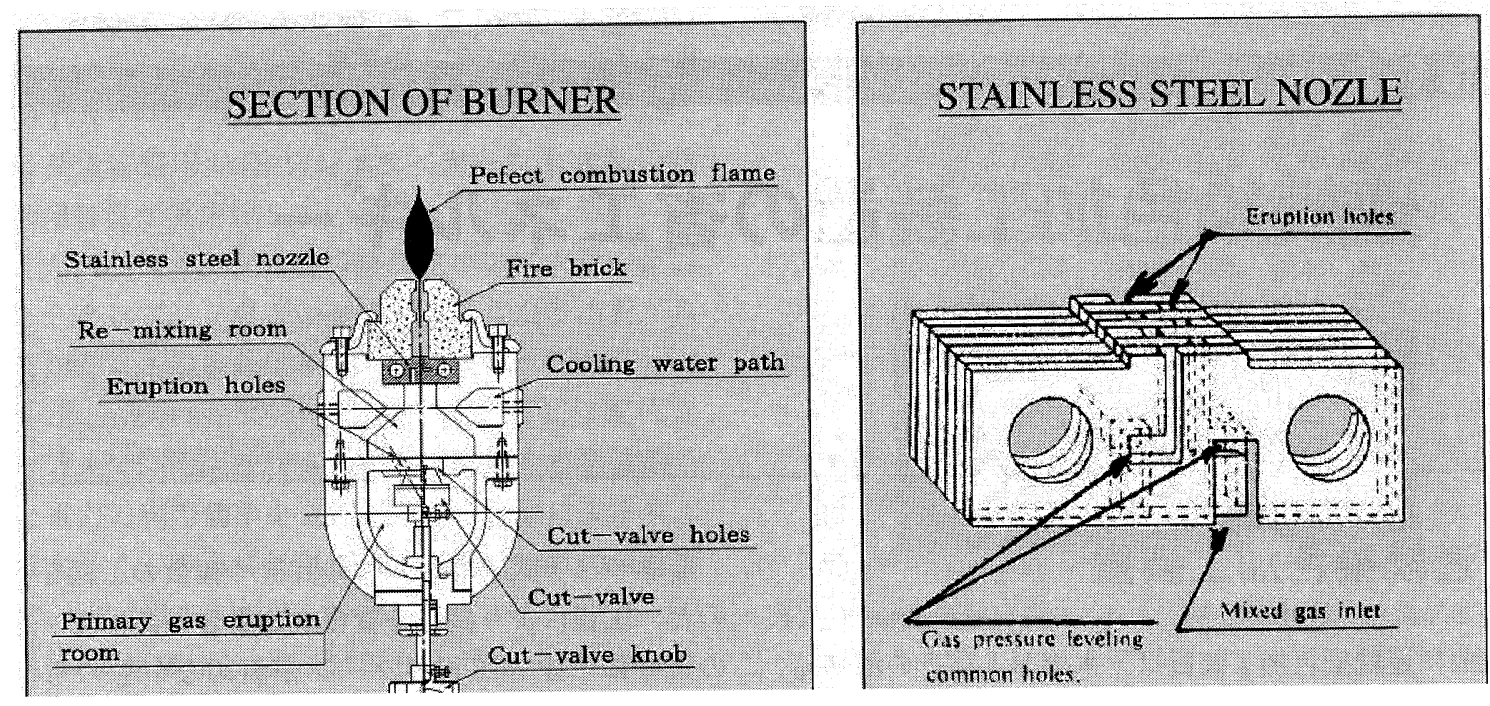

図 1 サンジェット毛焼バーナー断面図と調圧機構

なものが推奨される.

糊抜き装置や精練用リアクターやそれに続く水洗槽 は，ステンレス製であるから装置表面温度が $100^{\circ} \mathrm{C}$ 前後 であり, これらを発泡スチロールやロックウールボード をエポオキシ接着郕で固定し，保温することにより省エ ネを図っている.

リアクターは極カコンパクトな構造で放熱ロスを減少 させ，且つ動力用電力を最少化できることから，山東鐵 工所のRP-L型に代表されるラウンドパイル方式（図2） が省エネ・品質・生産性の面で世界的に評価されてい る。な扔，サチュレータでの薬夜含浸はWet on Wet方 式となるために絞りマングルは, 全幅にわたって均一で 高水分率な絞りを可能としている，精練剤であるか性ソ ーダは木綿に対して強い親和力を持つのでサチュレータ のか性ソーダ濃度は, 加工が進むと低下して行く, その ためにサチュレータのか性ソーダ濃度の管理に, 濃度コ ントロール装置の設置が必須となる。これを意ると染色 後の濃度バラツキが起こり, 不良・再加工の原因となり 多大のエネルギーを要することとなる.

\section{4. 漂白装置}

先の精練工程に続いて漂白工程が必要である. 通常は 精練工程の洗浄後濡れた状態で漂白装置のサチュレータ にて, 漂白薬荗がWet on Wetで含浸される. 木綿布で 最高の白度を要求される漂白法は, 従来は带塩素酸ソー ダ法が採用されていたが, 世界的なハロゲン物質排除の 流れを受け，塩素系漂白から過酸化水素漂白への転換が 図られている. 亜塩素酸ソーダの分解速度制御はギ酸が 主に用いられるが, 過酸化水素では逆にアルカリ剤が用 いられる. 通常「ラピッド漂白法」では常圧蒸熱法が主 に採用されている. 省エネや過酸化水素の効率的な漂白 法としてコールドバッチ法も多くの企業で採用されてい

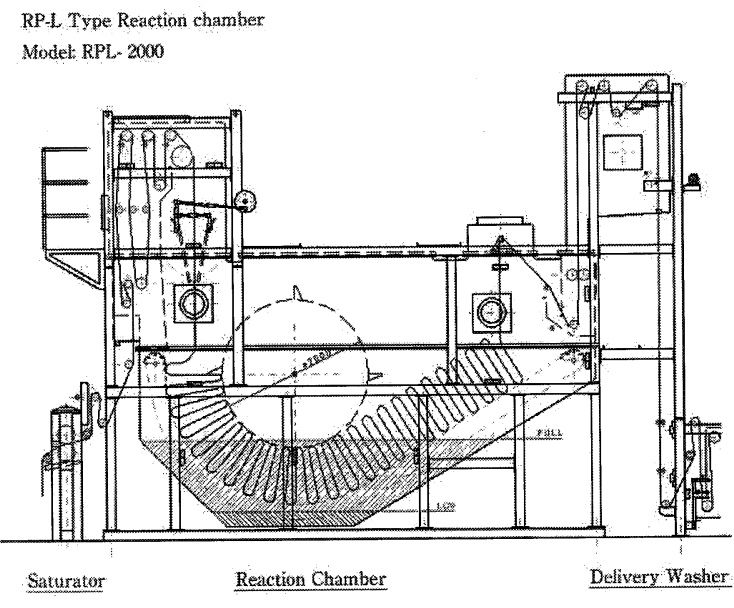

図2 精練・漂白用リアクター パーブルレンジRPL

るが, 処理時間が掛かることと, 白度が今ひとつ上がら ないことからその採用は部分的である.

常圧蒸熱法では蒸熱時に水分が十分あることが必須 で, 過熱蒸気がボイラーから送られている場合は, 蒸気 減温装置を併用して水分補給の必要がある. 過熱蒸気で は漂白効果が低下する。同時に過酸化水素分解抑制剂 （安定剤）の選択と使用量も重要なファクターである. 漂白装置（リアクター）は山東鐵工所のラウンドパイル 方式（図2）は，躯体がコンパクトで蒸気の分布が均一 で生地への張力, すれ，シワ等が最少化されている。こ のリアクターは, 保温材を適応しており, 精練装置と同 様に大きな省エネ効果がある.

\section{5. マーセライズ装置}

木綿を高濃度 $\left(20 \sim 25^{\circ}\right.$ Be') のか性ソーダで処理す ることにより, 木綿布帛の寸法安定性や染色濃度の向上 が大きく, 多くの木綿捛よびその混紡織編物はマーセラ イズ処理を行うことが定法とされている. 
特に最近では丸編み木綿ニットの高付加価值化が求め られ，拡布状マーセライズ装置の需要が高まっている. (図3)

マーセライズ工程そのものは常温で加工されるので省 エネの対象とならない，僅かであるが，カスケード洗浄 用のポンプや，テンター部分での吸引ポンプのインバー 夕化による電力の省エネは可能である.

精練工程において記述したように，か性ソーダは木綿 に対して強い親和力を持つので，か性ソーダを木綿から 離脱させるのは非常に困難である.さらに布地にか性ソ ーダが残存すると, 次工程の染色や白仕上げであれば, 蛍光染料や発水剂等の仕上加工剂との相溶性の問題が発 生し不良品の原因となる. 従ってマーセライズ後の布地 にか性ソーダが残存しないかどうかのチェックが常時行 われている．染色や仕上げ前にも再チェックを実施する 企業もある．このか性ソーダの除去には熱水で煮沸洗浄 を繰り返すか，か性ソーダを酸で中和させる．これはソ ーダ塩とすれば木綿との親和性がなくなるので洗浄が楽 であるからである. しかし，中和させる酸が多くなって 布地に残存して乾燥されると布地の脆化が危惧されるの で，者沸により大半のか性ソーダを洗い去り，最後に少 量の酸で中和する方法が採られている．酸中和による省 エネは $10 \%$ 以上となる，ただし，中和に必要な酸の選定 と濃度の管理の徹底が必要である。また, 熱水での煮沸 洗浄後の廃液の熱回収は, 重要で熱交換器の性能維持が できれば大きな省エネルギー化が図れる。

マーセライズは濃厚な, か性ソーダ処理であるが，そ の温度も重要なファクターであって, 効果を増進させる には $10^{\circ} \mathrm{C}$ 前後が良いとされ，この温度を維持するため にチラーが必要である．歴史的には電動冷凍機が用いら れているが，省エネの観点からは場内から出る廃熱を利 用する吸収式チラーの採用が推奨される.

さらに，マーセライズ工程から低濃度（2.5～3\%）の か性ソーダが排出される。これを減圧蒸散方式の濃縮装 置が使われているが，このエネルギーも主に蒸気が使用 されており，廃水の熱回収とともにプレート型熱交換機 を使用しているが, マーセライズ廃液からのスカムや空 気中の炭酸ガスどの反応で炭酸ナトリウムができ，これ らが付着して徐々に交換効率が劣化するので，配管や交 換機内部の洗浄が必要である.

\section{6. 洗浄・乾燥装置での省エネ}

染色加工工程でのエネルギー消費は，連続法，バッチ 法を問わず, 洗浄と乾燥が最大となる. 精練・漂白連続 染色のスチーミングを行うリアクターやヒートセット等 での乾熱処理でのエネルギーも処理装置や条件によって は，多くのエネルギーを消費する場合もあるがそれはよ ほど特殊なケースである.

連続装置の大半が洗浄装置と乾燥機がセットになって いる.この組み合わせは今日多くの洗浄方式と加工素材 により機構を異にしている。

\section{1 洗浄装置}

洗浄は精練漂白時の残留助剤やスカム, 繊維屑の除去. マーセライズでは余剒アルカリ，連続染色では吸尽され て未固着の染料等である.できるだけ少量の水とエネル ギーでこれらを布地から分離させるために各種の物理化 学的手法が用いられている. 特に温度と物理的振動が不 純物を除去するのに効果があるとされている．さらに污 染された洗浄水中では洗浄の限界があるために布地を污 濁の少ない洗浄水で洗う必要から槽を複数並べ, 布地を より清浄な水で洗浄する方法が採る必要から，槽の数が その生産性に合わせて増大していった。ここで節水と省 エネを両立させる方法として向流洗浄法が考案されその 成果は画期的であった．投入水量の減少が省エネにつな がる（図 4), 洗浄には布地が温水を含んでから不純物 の抽出に時間（タイミング）が必要なことから，1つの 槽での布の滞留量を, 温度を保持したままで増大させる 方法が各種考案されている．向流洗浄の考え方は，洗浄 槽間だけでなく，洗浄槽単独においてもその内部に水流 が布地の進行と逆行する構造とし, より効果的な節水と 省エネが達成されている．また，さらに節水化するため 洗浄水の再利用を促進し洗浄に適さなくなるまで水を再 利用してトータル水量の削減が可能である. 一方，編物 や弾性糸を使用した布地は連続法での洗浄が不利であっ たが，布地をコンベアーや多孔シリンダーで搬送し（図 5), 布地に張力を掛けない機構が開発され，バッチ式か らの脱却が図られている.

これらの洗浄装置では布地が槽と次の槽に移動する場 合に，前の槽での污濁物を次の槽への持ち达み (carry

OPEN KNIT MERCERIZER

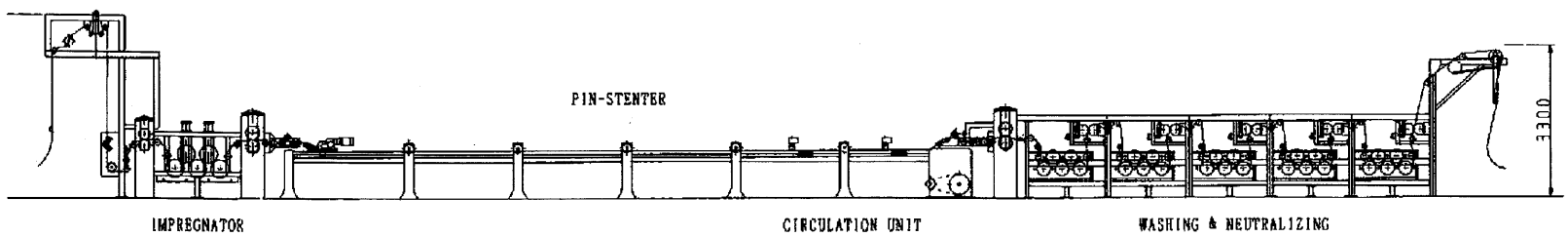

図3

山東鐵工所製＼cjkstart拡布状ニット用マーセライズ装置 

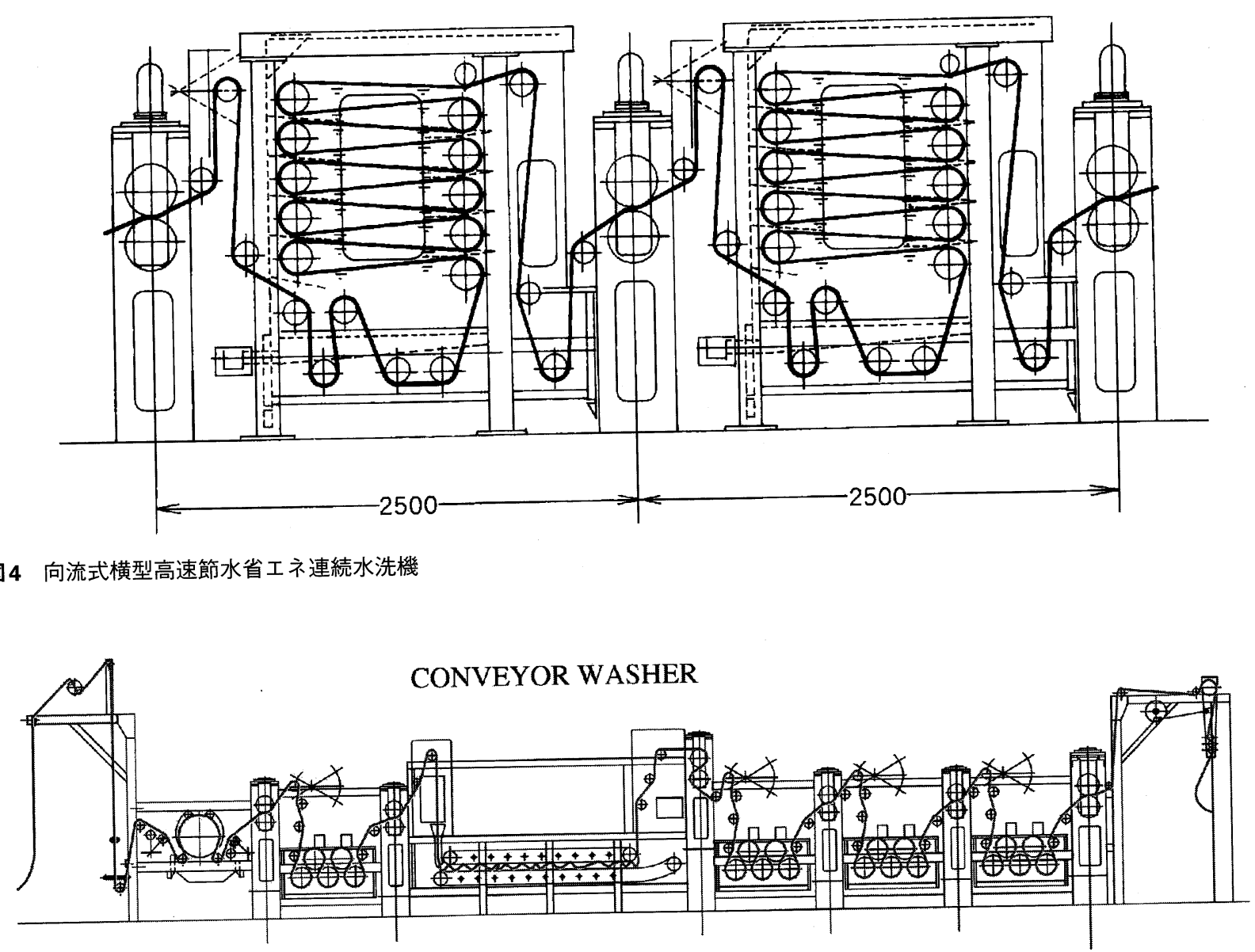

図 5 低張力節水・省エネ連続洗浄装置

over)を最少化するために脱水装置が設けられている. この装置は通常は絞りロールが多く, 金属ロールとゴム ロールの間に圧力を掛ける機構であるが, 素材や污濁の 内容によっては吸引脱水やスクレーパーで掻き取る機構 が用いられる．この絞り機構の直前で清浄水をスプレー で噴射されるケースを見ることがある．污濁物を次の槽 に持ち込まないために, 最後に清浄水で Carry overを 減らそうとの考えであるが, 高温水の噴射ならそれなり の効果はあるのかも知れないが冷水の噴射では効果は疑 問である．さらに布地が薄い場合は清浄水による Carry overの置換は考えられるが厚い布地では，その内部に ある Carry overを減少させることは難しい.

漂白工程の後の洗浄では多量の木綿滓が絞りロールの 表面に付着する。これによって絞り率が低下し Carry overの増加や, 最終の絞り不足による乾燥エネルギー の消費増につながる。そのために洗浄槽中の繊維㳯を除 去するフィルター機構やローラー表面から繊維滓を除去 する機構が考案されている.

投入熱量は投入水量に比例して増加する. 投入水量は 洗浄装置での洗浄効果によって決定されねばならない.

この洗浄効果は布地に付着する各種不純物によりその 内容は異なるが, 洗浄過程にある布地の洗浄効果を把握
することは不可能に近い. その代替えとして洗浄槽中の 浴の状況を簡易的に測定し，供給水量を把握すれば，か なり大きな省エネとなる. 染色加工のあらゆる工程で各 種の塩や, 酸・アルカリが使用されている.これにより 洗浄水は大きな伝導度（1000～10000 $\mu \mathrm{s} ）$ を持ってお り，工業用水 $(25 \sim 100 \mu \mathrm{s})$ との差は大きく測定が簡 単であり伝導度計も原理的に故障や誤差が少ない.これ らの計測器を使用し水を再利用することにより節水・省 エネが可能になる.

なお，洗浄水は，高温であるほどその洗浄効果は大き い.しかし, 現在の多くの連続式洗浄装置は生蒸気吹き 込みのために， $85^{\circ} \mathrm{C}$ 以上になると突沸を起こしたり， 布地を摇らせる原因となるため, 突沸による蒸気エネル ギーロスを回避し生地を摇らさず安定的に走行できる方 式も採用が増えてきている，山東鐵工所では，突沸を回 避しながら高温度で洗浄できるように，間接加熱夕イプ も採用している，省エネには温排水の廃熱回収が常識と なっている現在では, 温水夕ンクが備えてあり，そこか ら熱回収温水が洗浄装置に供給されているはずである. この温水タンクに加熱に必要な蒸気コイル等の熱交換設 備を付加し, 向流洗浄槽で加温の必要な槽には蒸気加温 パイプを配して追加加温する.これにより処理に高価な 
純水装置や軟化処理したボイラー用水の回収率が増加 し，コスト削減にもつながる.

\section{2 乾燥装置}

連続加工方式の欠点は, 各種の工程が単一の装置です ベて行えず，それぞれ固有の機能をもつ装置を順次組み 合わせて目的とする製品に到達することにある．そのた め個々の装置での単一操作が終われば，布地を乾燥させ る必要がある. もちろん, 大ロットで比較的単純な加工 では幾つかの単一処理を乾燥せずに, Wet on wetで連 結する場合もあるが, 昨今の国内での加工では小ロット 多品種で有るが故に, 単一操作ごとに乾燥工程を介在せ ざるをえなくなっている.

この乾燥装置は, 処理される素材により各種の機構の ものが使われている. 木綿およびその混紡品織物にあっ てはシリンダー乾燥装置, ポリエステル織物や編物にあ っては, コンベアー式乾燥機が一般的であろう. シリン ダー乾燥機は布地が加温された金属表面に直接接触して 熱を伝える機構から, 最も効率の良い乾燥装置であるが, 加熱金属体が外気に裸で暴露されてており，布地の非接触 部分の保温が大きな効果をもたらす．ロックウールを両 サイドの鏡面に吹き付けや耐熱合板での覆い等はメーカ 一のオプションで調達可能である.

最近では放散される蒸気をダクトで回収し冷水を加温 する装置も開発されている。

さらに, 乾燥装置でありがちなのは過乾燥によるエネ ルギーの無駄である. 乾燥直後の布地表面の温度または 水分量を連続的に測定して乾燥装置への熱源コントロー

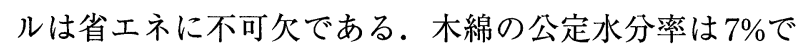
あり，それ以上の乾燥は無駄である。この水分率で管理 すれば，7\%が省エネとなる．ポリエステルは水分率が 0\%であるが, 表面温度が $100^{\circ} \mathrm{C}$ 以上は無駄であり折れ シワの原因になる, そのために乾燥装置の最後に冷却装
置を備えている. 冷却装置の前で布表面温度が $100^{\circ} \mathrm{C}$ 以 下が望ましい.

\section{7. 総 括}

連続法による染色加工は, 今日でも高生産性は強く望 まれている. しかし, 従来の大ロット少品種の時代では, 高生産性が省エネにも結びついたこともあった.

現在の染色加工装置に求められている省工ネは, 単位 時間内での省エネである, つまり機能を殺さずに投入工 ネルギーの削減である，染色加工技術における省エネの 壁は，水を媒体としているところにある.このことから 過去に山東鐵工所は水を使用しない染色加工装置として 連続プラズマ装置やオゾン漂白装置等を開発した. しか し, 時代の流れが小ロット多品種となりバッチ式の優位 さが顕著になり大型連続装置は時代にマッチしないとの 業界の判断があった.

しかし, 良質の水の枯渇, 排水処理費の高騰, 省工 ネ. 地球温暖化防止等の観点から連続方式への回帰も見 られる. 染色加工での水は不可欠であるが, その極少化 と温排水からの廃熱回収, 排水再利用がこれからの染色 加工事業にとって必須条件である.これには多くの水を 使用するバッチ式に比して, 連続式が有利である。効率 的な水使用や省エネは現代のIT技術で開発されている センサーや制御装置の導入により, 以前は不可能であっ たことが今日では可能となっている, 特に電力はインバ 一夕装置の普及と価格低下により過去 10 年間で画期的 な変貌を遂げている。しかし, 例えば, 洗浄後の絞り装 置の連続脱水率のアップ等の業界独自の具体的命題もあ る.これ等は永遠の課題かも知れないが, 山東鐵工所で は果敢な挑戦を行っている.

山東幸司(さんどうこうじ) 1986 年, (株山東鐵工所に入社、技術部にて機械設計に従事. 2006 年より経営企画室室長， 現在に至る。

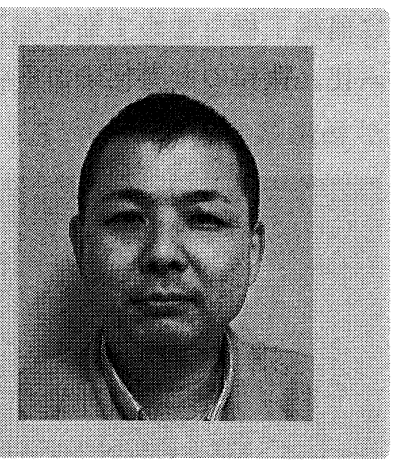

